УДК 664

DOI https://doi.org/10.32838/2663-5941/2020.4/30

Восвода Н.В.

Херсонський державний аграрно-економічний університет

Легутенко А.C.

Херсонський державний аграрно-економічний університет

\title{
ОПТИМІЗАЦІЯ ТЕХНОЛОГІЇ ВИРОБНИЦТВА ІКРИ ОЗДОРОВЧОГО СПРЯМУВАННЯ 3 ГАРБУЗОМ
}

Стаття присвячена важливому питанню розширення асортименту консервної продукиії оздоровчого спрямування в умовах ТОВ «Плодоовочевий комбінат «Херсон» (м. Херсон). У зв'язку з високою харчовою цінністю та позитивним впливом на шлунково-кишковий тракт людини наведена етапність виробництва овочевої ікри з модифікованим складом. Він базується на таких компонентах, як баклажани, гарбуз та чорнослив, які відомі високим вмістом нутрієнтів та зазначені у рецептурі. Таким чином, для сегменту споживачів, що мають захворювання шлунково-кишкового тракту та печінки, стає можливим споживання закусочних консервів. Для їх збереження пропонується замінити класичний процес обжарювання компонентів рещептури згідно з ДСТУ 3797-98 «Консерви. Ікра овочева. Технічні умови» на бланшування, щьо дає змогу не тільки позбавитись природної гіркоти баклажан, а й зменшити енергетичну цінність готової продукиії. Опис технологічного процесу виробництва включає наведені параметри переробки продукиії на різних етапах вироблення консервів. Як результат досліджень стаття містить узагальнену технологічну схему виробництва овочевої ікри оздоровчого спрямування в умовах ТОВ «Плодоовочевий комбінат «Херсон» (м. Херсон). При иъьому зазначено, щяо некондииійна сировина та відходи виробництва транспортуються за територію иеху в спеціальних контейнерах, які передаються іншим юридичним особам для подальшої переробки, тому виключений негативний вплив на навколишне природне середовище внаслідок нераціональної їх утилізації.

Перспективи подальших досліджень пов'язані з розрахунком харчової иінності, визначення етапності організачії забезпечення та контролю якості консервів, що включає виділення контрольних точок у відповідності до системи аналізу ризиків, небезпечних чинників $і$ контролю критичних точок НАССР, а також виробництвом пробної партії у виробничих умовах.

Ключові слова: закусочні консерви, овочева ікра, оздоровче харчування, технологічна схема, модифікований склад, технологічні параметри.

Постановка проблеми. Овочеві закусочні консерви відіграють велику роль у харчуванні людини, проте полікомпонентна система рецептурного складу передбачає специфічну підготовку кожного складника, зокрема смаження, для досягнення специфічних органолептичних показників та термічної усадки сировини. Однак ця методика позначається негативно на шлунково-кишковому тракті споживача 3 урахуванням регулярного споживання, а корисне харчування має стійку тенденцію до збільшення обертів. Тому запропоновані консерви оздоровчого харчування, а саме баклажанної ікри $з$ модифікованим складом [1], є альтернативою класичним консервам. Таким чином, необхідно скласти технологічну схему виробництва такої продукції в умовах ТОВ «Плодоовочевий комбінат «Херсон» (м. Херсон), що забезпечить не тільки розширення сортименту консервів підприємства, а й стабіль- ний розвиток харчової промисловості та економіки регіону загалом.

Аналіз останніх досліджень і публікацій. Проблема покращення харчування спонукала до інноваційних досліджень багатьох учених, зокрема М.Я. Бомба та С.Ю. Колодій оцінювали можливість адаптації калорійних традиційних вітчизняних страв до вимог дієтичного харчування у зв'язку з погіршенням стану здоров'я населення [2]. Відзначимо, що В.С. Іванченков та 3.В. Чехович [3] розглядали питання популяризації здорового харчування крізь призму інновацій та стабільного економічного розвитку підприємств Півдня України. Зазначимо, що розробкою овочевої ікри підвищеної харчової цінності, до рецептури якої було введено нетрадиційну сировину - пюре 3 шипшини, пряноароматичну сировину - імбир та рапсову олію, займались Н.В. Дуденко та В.С. Ольховська [4]. 
Проте іiі основною сировиною $є$ кабачки, які піддаються термічній обробці шляхом обжарювання. На нашу думку, перспективним напрямом $\epsilon$ не тільки модифікація рецептурного складу, а й заміна традиційних технологічних процесів.

Постановка завдання. Мета публікації скласти технологічну схему виробництва овочевої ікри з баклажанів оздоровчого спрямування 3 деякими оптимальними технологічними параметрами переробки сировини.

Виклад основного матеріалу дослідження. Продукт оздоровчого харчування - продукт, як правило, з фортифікованим вмістом певних дефіцитних нутрієнтів, що забезпечує його позитивний вплив на здоров'я людини. Склад таких харчових продуктів повинен значною мірою відрізнятися від складу звичайних продуктів подібного роду, якщо такі звичайні харчові продукти існують, але не можуть бути замінниками лікарських засобів [5].

Натепер сегмент ринку з виробництва харчових продуктів постійно збільшується, проте він включає здебільшого кондитерські вироби, готові сніданки та молочні продукти із застосуванням інноваційних компонентів, які рідко включаються до харчового раціону. Розширити цей сегмент можна за рахунок виготовлення у промислових умовах консервів, які до цього часу мали високу калорійність та були шкідливими у разі деяких порушень організму людини [6; 7]. Тому постає необхідність знайти рішення у використанні нетрадиційної сировини у складі рецептури класичних закусочних консервів та зробити їх доступними для всіх бажаючих. Отже, проаналізуємо технологічні операції, які пропонуємо проводити під час виробництва овочевої ікри з гарбузом.

Сировину подають на лінію первинної переробки в порядку надходження іiї на підприємство 3 урахуванням якісного стану кожної партії. Для підготовки овочів сировина у контейнерах направляється на контейнероперекидач, який подає їх на виробничу лінію і дає змогу очищати від сторонніх домішок.

Баклажани перед початком переробки сортують, а потім ретельно миють у мийній машині 3 пристроєм для попередньої мийки і ополіскують під душем у цій же машині. Наступним етапом інспектують сировину і потім знову ополіскують під душем за тиску води 2-3 кгс/см² (200-300 кПа), після чого направляють на нарізання.

Після цього вносимо пропозицію замінити технологічну стадію обжарювання згідно з ДСТУ 3797-98 «Консерви. Ікра овочева. Технічні умови»
[8] на бланшування парою, внаслідок чого збільшиться поживна цінність та зменшиться енергетична цінність продукту. До того ж, окрім позитивного впливу на шлунково-кишковий тракт як комфортного травлення базовими компонентами ікри, він підсилюється включенням у склад чорносливу, який додатково чинить позитивний вплив на органолептичні показники ікри [1]. У технологічному сенсі бланшування дає змогу позбавитись природної гіркоти продукту та виключити появу темних цяточок у готовій продукції (дефект, що виникає у разі підгоряння шкірки під час обжарювання), а після цього баклажани подрібнюють на протиральній машині з отворами решіток діаметром 10 і 3,5 мм.

Плоди гарбуза, призначені для приготування ікри, попередньо сортують. Мета сортування полягає в тому, щоб видалити не придатні для виробництва плоди. Після сортування гарбуз миють. Під час миття гарбуз звільняється від бруду. Після мийки гарбуз ошпарюють, при цьому він розм'якшується за рахунок розпаду протопектину. Під час водяного ошпарювання гарбуз занурюють у киплячу воду на 7-10 хвилин, внаслідок чого знижується і бактеріальна забрудненість гарбузової маси. Потім воду зливають, а гарбуз протирають. Вода, що залишилася, містить розчинні речовини, частково витягнуті з гарбуза, тому вона додається в протерту масу. Ошпарений гарбуз протирають. Для протирання використовують сітки 3 діаметром отворів 1,5-2,0 мм [9].

Моркву сортують за якістю, відбирають дефектні коріння, калібрують за довжиною та діаметром. Миють коріння в послідовно встановлених мийних машинах: барабанній і уніфікованій до повного видалення всіх забруднень. У разі значних забруднень коренеплодів їх попередньо замочують у ванні з чистою проточною водою. Якість миття систематично контролюється. Коренеплоди повинні бути повністю відмиті від залишків землі та інших забруднень, які є джерелами попадання в продукт спор мікроорганізмів. Після миття у коренеплодів обрізають залишки бадилля 3 частиною коренеплоду (по лінії зеленої грані) i тонку частину кореневища. Всі корені товщиною менше 5 мм (як основні, так і бокові) повинні бути видалені, видаляють також усі пошкоджені місця. Обрізають коріння на машинах або вручну на конвеєрі. Очистку моркви проводять механічним способом. Очищені коренеплоди піддають ретельному миттю. У разі неповного зняття шкірки проводять доочищення вручну й ополіскування [10]. 
Чорнослив інспектують, замочують у теплій $\left(40-45{ }^{\circ} \mathrm{C}\right)$ воді впродовж 30 хв., потім промивають у проточній воді до повного видалення піску та інших забруднень. Набухання під час замочування повинне бути у середньому в межах $111-115 \%$, після чого проводять подрібнення.

Вміст нікотинової і пантотенової кислот дає змогу назвати чорнослив хорошим засобом для лікування захворювань шлунково-кишкового тракту. Регулярне вживання сухофрукта сприяє поліпшенню стану у разі підвищеного тонуса судин, слабкості у м'язах, у разі кишкової непрохідності. Що стосується чорносливу, як і інші сухофрукти, він має послаблюючу дію. У невеликих кількостях містить відомі антиоксиданти вітамін Е та аскорбінову кислоту. Вони дають організму силу та енергію, борються 3 онкологічними захворюваннями та підвищують імунітет.

Послаблююча дія цього сухофрукта зумовлена наявністю в ньому великої кількості калію, який $\epsilon$ відмінним засобом для лікування деяких захворювань кишечника. Калій також корисний у разі захворювань серцево-судинної системи. Окрім цього, він містить фосфор, магній і кальцій, а вони корисні для зубів і кісток [11].

Зелень передбачено після приймання сортувати, після чого мити душовим методом. Миту свіжу сировину інспектують за якістю та подрібнюють шляхом нарізання.

Цибуля подається на землевідділювач, після чого потрапляє в машину для комплексної очистки та обрізання шийок та мочок у цибулин. Далі вона направляється на бланшування у киплячій воді у цілому вигляді протягом 3-5 хв. [12].

Рослинну олію проколюють у варочному котлі, яку після охолодження через отвір для зливу збирають у спеціальні ємності.

Томат-пюре протирається на протирочній машині, збирається та обігрівається у збірнику; якщо необхідно, то розбавляється там водою і також передається насосом-дозатором у змішувач.

Білі корені після ретельного миття у мийних машинах ретельно очищуються та бланшуються. Після бланшування надходять у змішувач компонентів за рецептурою.

Сіль та прянощі просіюють та проводять магнітну сепарацію.

Компоненти рецептури ретельно змішують у спеціальному апараті 3 двостінною нагрівальною камерою до повного розчинення солі і цукру й отримання однорідної маси. Після цього відбувається протирання маси у протирочній машині із ситами, отвори яких мають діаметр 1,2 мм. Зазначимо, що продукт після такого впливу має більш пастоподібну консистенцію. Готову ікру за допомогою шнекового транспортера фасують у тару за температури маси $70-80{ }^{\circ} \mathrm{C}$ на автоматичному наповнювачі у склобанки I-82-500. Не допускається розривів між закупорюванням i стерилізацією понад 30 хв. Банки негайно укупорюють на укупорювальній машині, вони потрапляють на накопичувач банок, після чого їх передають на стерилізацію у вертикальних автоклавах. Температура стерилізації продукції становить $120-130{ }^{\circ} \mathrm{C}$. Рецептура ікри 3 баклажанів та гарбуза наведена у табл. 1.

Таблиця 1

Рецептура запропонованої ікри з баклажанів та гарбуза

\begin{tabular}{|l|c|}
\hline \multicolumn{1}{|c|}{ Компонент } & $\begin{array}{c}\text { Норма } \\
\text { витрат на } \\
1 \text { кг ікри, г. }\end{array}$ \\
\hline Баклажани & 687 \\
\hline Гарбуз & 630 \\
\hline Морква & 55 \\
\hline Білі корені & 27 \\
\hline Цибуля свіжа & 82 \\
\hline Чорнослив & 92 \\
\hline Зелень & 5 \\
\hline Сіль & 15 \\
\hline Цукор & 7 \\
\hline Перець чорний молотий & 0,5 \\
\hline Перець запашний молотий & 0,5 \\
\hline Томат-пюре із вмістом СР 12\% & 187 \\
\hline Олія & 32 \\
\hline
\end{tabular}

Склотара з цехового складу надходить на обполіскування у теплій воді за $35-40{ }^{\circ} \mathrm{C}$ і обробку парою на ополіскувальній машині і шпарці. Кришки СКО перед закупорюванням піддають шпарці в ємності з водою, куди подається пар. Підготовлені банки конвеєром подають на фасування.

Некондиційна сировина та відходи виробництва транспортуються за територію цеху в спеціальних контейнерах, які передаються іншим юридичним особам для подальшої переробки.

Як результат складено узагальнену технологічну схему виробництва овочевої ікри 3 модифікованим складом оздоровчого спрямування (рис. 1). 


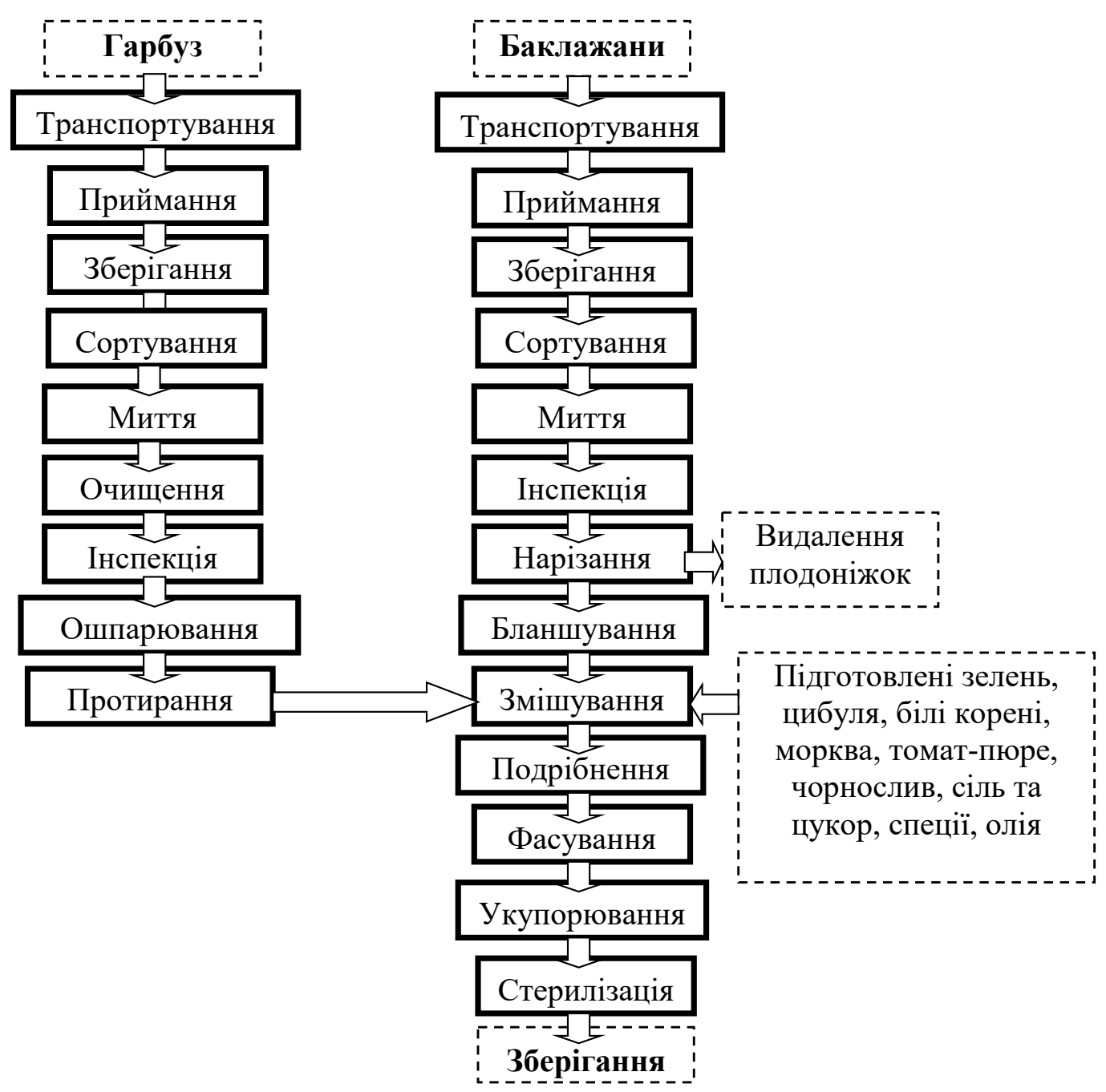

Рис. 1. Технологічна схема виробництва овочевої ікри оздоровчого спрямування

Стандартом передбачається вміст сухих речовин в ікрі з баклажанів - не менше $24 \%$; вміст солі - 1,2-1,6\%. Титрована кислотність у розрахунку на яблучну кислоту в ікрі з баклажанів - не більше $0,5 \%$ [13].

Таким чином, полікомпонентний склад закусочних консервів дає змогу отримати цікавий за органолептичними показниками продукт, проте варто зазначити, що трудомісткий технологічний процес мусить проводитись без простою, адже саме цей фактор матиме вирішальну роль у разі накопичення патогенної мікрофлори.

Висновки. У результаті проведених досліджень складена узагальнена технологічна схема виробництва закусочних консервів, а саме овочевої ікри модифікованого складу. Зміна класичних компонентів дає змогу отримати новий за органолептичними показниками продукт, який не шкодить здоров'ю споживачів та може використовуватись у харчуванні осіб, що мають порушення функціонування шлунково-кишкового тракту та печінки. Це припущення базується на обгрунтованій 3 технологічної точки зору заміні класичного обжарювання сировини у паромасляній печі або печі Крапівіна на бланшування парою та водою. При цьому приємний присмак та післясмак готовій продукції надаватиме чорнослив.

Подальші дослідження пов'язані з розрахунком харчової цінності продукту, визначення етапності організації забезпечення та контролю якості консервів, які висвітлені у загальній схемі хімікотехнологічного та мікробіологічного контролю продукції та включає виділення контрольних точок у відповідності до системи аналізу ризиків, небезпечних чинників і контролю критичних точок НАССР, а також виробництвом пробної партії у виробничих умовах. 


\section{Список літератури:}

1. Воєвода Н.В. Перспективи застосування гарбуза у промисловому виробництві овочевої ікри. Актуальні проблеми підвищення якості та безпека виробництва й переробки продукиії тваринництва : матеріали міжнар. наук.-практ. конф., м. Дніпро, 14 лютого 2020 р. Дніпро, 2020. С. 338-339.

2. Бомба М.Я., Колодій С.Ю. Адаптація українських національних страв до сучасних вимог харчування. Новітні тенденції у харчових технологіях та якість і безпечність. 2015. С. 127.

3. Іванченков В.С., Чехович 3.В. Перспективи інноваційного розвитку консервного виробництва в Українському Причорномор’ї. Економічні інновації. 2015. № 60 (1). С. 154-171.

4. Дуденко Н.В., Ольховська В.С. Математичне моделювання овочевих консервів із заданими споживчими властивостями. Вісник НТУ «ХПІ». Серія: Нові рішення в сучасних технологіях. 2013. № 1 (977). C. $116-122$.

5. Євлаш В.В., Серік М.Л., Горбань В.Г., Мурликіна Н.В. Опорний конспект лекцій з дисципліни «Інноваційні технології дієтичних харчових продуктів» для студентів освітнього ступеня магістр спеціальності 181 «Харчові технології» освітньо-професійної програми. Харків : ХДУХТ. 2019. 79 с. URL: http://elib.hduht.edu.ua/bitstream/123456789/5203/1/2019.1_поз.50.pdf.

6. Мімахіна М., Науменко Н. Інновації у харчових технологіях. Товари і ринки. 2015, № 1. С. 189-201.

7. Шкода і користь консервів: на що слід звертати увагу під час покупки. URL: https://vbusk.com/cikavo/ shkoda-i-koryst-konserviv-na-shcho-slid-zvertaty-uvahu-pry-pokuptsi.html (дата звернення: 30.01.2020).

8. ДСТУ 3797-98. Консерви. Ікра овочева. (Чинний від 2000-01-01). Вид. офіц. Київ : Держстандарт України, 2000. 14 с.

9. Использование пюре из тыквы в пищевой промышленности. URL: https://n-wrc.ru/blog/ispolzovaniepjure-iz-tykvy-v-pishhevoj-promyshlennosti/ (дата звернення: 20.07.2020).

10. Икра овощная. Технологическая схема. URL: http://prodkonslab.ru/texnologicheskie-sxemy/ikraovoshhnaya.html (дата звернення: 30.01.2020).

11. Користь та шкода чорносливу для людського організму. URL: https://www.yizhainfo.pp.ua/korist-tashkoda-chornoslivu-dlya-lyudskogo-organizmu/ (дата звернення: 19.07.2020).

12. Особенности отдельных видов овощных консервов. URL: http://www.comodity.ru/ovoshkonserv/ kinds/3.html (дата звернення: 22.07.2020).

13. Назарова А.И., Фан-Юнг А.Ф. Технология плодоовощных консервов. Москва : Легкая и пищевая промышленность. 1981. 239 с.

\section{Voievoda N.V., Legutenko A.S. OPTIMIZATION OF PRODUCTION TECHNOLOGY OF HEALTH ORIENTATION CAVIAR WITH PUMPKIN}

The article is devoted to the important issue of expanding the range of canning products for health purposes in the conditions of Ltd. "Fruit and vegetable factory "Kherson" (Kherson). Due to the high nutritional value and positive impact on the human gastrointestinal tract, the stages of production of vegetable caviar with a modified composition are given. It is based on ingredients such as eggplant, pumpkin and prunes, which are known to be high in nutrients and specified in the recipe. Thus, for the segment of consumers with diseases of the gastrointestinal tract and liver, it becomes possible to consume canned. To preserve them, it is proposed to replace the classic process of frying the components of the recipe in accordance with DSTU 3797-98 "Canned food. Vegetable caviar. Technical conditions" for blanching, which allows not only to get rid of the natural bitterness of eggplant, but also to reduce the energy value of finished products. The description of the technological process of production includes the given parameters of processing of products at different stages of production of canned food. As a result of researches, the article contains the generalized technological scheme of production of vegetable caviar of improving direction in the conditions of Ltd. "Fruit and vegetable factory "Kherson" (Kherson). It is noted that substandard raw materials and production waste are transported outside the shop in special containers, which are transferred to other legal entities for further processing, so the negative impact on the environment due to their irrational disposal is excluded.

Prospects for further research are related to the calculation of nutritional value, determining the stages of organization of quality assurance and quality control, which includes the selection of control points in accordance with the system of risk analysis, hazards and control of critical points HACCP, as well as trial production in production conditions.

Key words: canned snacks, vegetable caviar, health food, technological scheme, modified composition, technological parameters. 